Volume. 7 Nomor. 2, Mei 2020. p - 2354-8649 I e - 2579-5767

Open Access at: http://ojs.umrah.ac.id/index.php/selat

DOI: https://doi.org/10.31629/selat.v7i2.1739

\title{
IMPLEMENTASI RESTRUKTURISASI DALAM PROSESI KEPAILITAN DAN PENUNDAAN KEWAJIBAN PEMBAYARAN UTANG DI INDONESIA
}

\author{
Yudi Kornelis $^{1}$, Florianus Yudhi Priyo Amboro ${ }^{2}$ \\ ${ }^{12}$ Fakultas Hukum Universitas Internasional Batam \\ Email: yudi_kornelis@yahoo.co.id, yudhi.amboro@gmail.com
}

\begin{abstract}
In order to enforce the law in the field of bankruptcy, there are procedures that must be carried out by every justice seeker, namely bankruptcy procedures and suspension of payment. The procedure for bankruptcy and the suspension of payment begins with the application, then followed by the decision of the bankruptcy statement or the suspension of payment and all legal appeals. Inside this process will be found restructuring between debtors to avoid bankruptcy, both in the form of debt restructuring and corporate restructuring. The purpose of this study is to have a description of the implementation on restructuring regarding bankruptcy and suspension of payment procedures, and also to be a guide for optimizing the restructuring plan arranged by the debtor. This research has reached the result that the restructuring in the process of bankruptcy and suspension of payments is mostly the debt restructuring and begins with a settlement plan. Rescheduling is the most popular bankruptcy restructuring model and suspension of payment. In addition it is a combination of rescheduling and asset sales, finding new equity, as well as debt to equity swap. Obsession arises in the process when the debtor arranges a restructuring plan. Some cases show that the debtor's understanding of the use of the restructuring plan is the main reason for the constraint. In addition, the implementation of the restructuring may fail in some cases, citing the lack of ability of the debtor to handle business and debt.
\end{abstract}

Keywords; Bankruptcy, Suspension of Payment, Restructuring

\begin{abstract}
Abstrak
Dalam rangka untuk melakukan penegakan hukum di bidang kepailitan, terdapat prosedur yang harus dilakukan oleh setiap pencari keadilan, yaitu prosedur kepailitan dan penundaan kewajiban pembayaran utang. Prosedur kepailitan dan Penundaan Kewajiban Pembayaran Utang dimulai dengan permohonan, kemudian dilanjutkan dengan putusan pernyataan pailit maupun Penundaan Kewajiban Pembayaran Utang dan keseluruhan upaya hukumnya. Proses tersebut di dalamnya akan ditemukan restrukturisasi antara debitor untuk menghindari kepailitan, baik berupa restrukturisasi hutang maupun restrukturisasi perusahaan. Tujuan penelitian ini adalah untuk mendapatkan deskripsi restrukturisasi dalam praktik tentang prosedur kepailitan dan penangguhan pembayaran, dan juga menjadi panduan untuk mengoptimalkan rencana restrukturisasi yang diatur oleh debitor. Penelitian ini
\end{abstract}


telah mencapai hasil bahwa restrukturisasi saat dalam proses kepailitan dan penangguhan pembayaran sebagian besar adalah restrukturisasi hutang dan dimulai dengan rencana penyelesaian. Rescheduling adalah model restrukturisasi kepailitan yang paling populer dan penangguhan pembayaran. Selain itu adalah kombinasi antara penjadwalan ulang dan penjualan aset, menemukan ekuitas baru, juga pertukaran utang ke ekuitas. Obsesi muncul dalam proses ketika debitor mengatur rencana restrukturisasi. Beberapa kasus menunjukkan bahwa pemahaman debitor terhadap penggunaan rencana restrukturisasi menjadi alasan utama kendala. Selain itu, pelaksanaan restrukturisasi mungkin gagal dalam beberapa kasus, dengan alasan kurangnya kemampuan dari debitur untuk menangani bisnis dan hutang.

Kata Kuncil; Kepailitan, Penundaan Kewajiban Pembayaran Utang, Restrukturisasi

\section{PENDAHULUAN}

Hukum Kepailitan Indonesia yang terdiri dari konsep kepailitan dan konsep Penundaan Kewajiban Pembayaran Utang (PKPU) untuk pertama kali diperkenalkan dalam Staatsblad 1905 No. 217 jo. Staatsblad 1906 No. 348. Selanjutnya, diperbaharui dalam Undang-Undang No. 4 Tahun 1998 dan pada akhirnya digantikan kedudukannya oleh Undang-Undang No. 37 Tahun 2004. Di dalam melakukan penegakkan hukum di bidang kepailitan ini, terdapat prosesi yang harus dijalankan oleh setiap pencari keadilan yaitu proses Kepailitan maupun proses PKPU.

Proses Kepailitan diawali dengan adanya permohonan yang selanjutnya diperiksa dalam persidangan yang terbuka untuk umum guna mencapai persyaratan utama dalam Pasal 2 ayat (1) Undang-Undang No. 37 Tahun 2004 yaitu "Debitor yang mempunyai dua atau lebih kreditor dan tidak membayar lunas sedikitnya satu utang yang telah jatuh waktu dan dapat ditagih, dinyatakan pailit dengan putusan pengadilan, baik atas permohonannya sendiri maupun atas permohonan satu atau lebih kreditornya". Setelahnya, dilanjutkan dengan putusan pailit dengan segala upaya hukumnya. Jika debitor dimaksud telah dinyatakan pailit dalam putusan pengadilan niaga di tingkat pertama, maka prosesi selanjutnya adalah melalui proses pengurusan dan/atau pemberesan atas harta pailit, yang di dalamnya akan ditemukan restrukturisasi yang dilakukan oleh debitor untuk menghindarkan insolvensi, baik restrukturisasi utang maupun restrukturisasi perusahaan. Istilah yang umum digunakan di dalam bidang kepailitan adalah perdamaian.

Dalam proses PKPU, sebagaimana juga proses Kepailitan di atas, diawali dengan adanya permohonan yang selanjutnya diperiksa dalam persidangan yang 
terbuka untuk umum guna mencapai persyaratan utama dalam Pasal 222 UndangUndang No. 37 Tahun 2004 yang pada intinya menyebutkan bahwa kreditor dan debitor yang tidak dapat atau memperkirakan tidak akan dapat melanjutkan membayar utang-utangnya yang sudah jatuh waktu dan dapat ditagih, dapat memohon penundaan kewajiban pembayaran utang, dengan maksud untuk mengajukan rencana perdamaian yang meliputi tawaran pembayaran sebagian atau seluruh utang kepada kreditor. Setelah memenuhi ketentuan tersebut, pengadilan akan melakukan penundaan kewajiban pembayaran utang sementara untuk masa paling lama 45 hari. Penundaan ini akan bisa menjadi bersifat tetap, jika debitor memenuhi ketentuan tertentu dan disetujui oleh kreditornya. Hal yang sama dengan prosesi kepailitan, bahwa dalam waktu penundaan terjadi, baik sementara maupun bersifat tetap, maka dalam hal ini debitor berkewajiban untuk mengajukan rencana perdamaian kepada para kreditornya. Disinilah letak restrukturisasi tersebut, baik restrukturisasi utang maupun restrukturisasi perusahaan debitor.

Fakta empiris dalam penelitian yang sebelumnya yang dilakukan oleh Manahan Sitompul ${ }^{1}$ dalam era tahun 1998-2006 disimpulkan bahwa perdamaian dalam prosesi kepailitan dan PKPU tidak optimal tercapai. Dalam penelitian lain yang dilakukan oleh Yudi Kornelis dan Florianus Yudhi Priyo Amboro², terungkap bahwa sebagian perkara kepailitan dan PKPU berakhir dengan perdamaian, meskipun ada sebagian lain yang berakhir dengan dinyatakan pailit dan pemberesan harta pailit. Terutama jika Kepailitan dan PKPU tersebut dimohonkan dengan dilandasi pada itikad tidak baik, misalnya debitor yang tidak jujur dan melarikan diri. Mungkin juga ada kreditor yang curang dengan memohon PKPU untuk mendapatkan title pailit bagi debitor, mengingat tidak adanya upaya hukum bagi PKPU dan dapat dilangsungkan dengan cepat. Tetapi dalam hal tercapainya perdamaian itu dapat terjadi dan rancangan atau rencana perdamaian yang telah disusun oleh debitor dapat memuaskan kepentingan kreditor, termasuk model restrukturisasi utang maupun model restrukturisasi perusahaan.

\footnotetext{
1 Manahan Sitompul M.P., "Penyelesaian Sengketa Utang Piutang Perusahaan Dengan Perdamaian Di Dalam Atau Di Luar Proses Kepailitan (Studi Mengenai Lembaga Penundaan Kewajiban Pembayaran Utang)" (Universitas Sumatera Utara, 2009).

2 Yudi Kornelis and Florianus Yudhi Priyo Amboro, Reorganisasi Dalam United States Bankruptcy Code Terhadap Ketentuan Penundaan Kewajiban Pembayaran Utang ( PKPU ) Dalam Hukum Kepailitan Indonesia Dengan Perspektif Budaya Hukum Indonesia (Batam, 2014).
} 
Berdasarkan rangkaian penelitian di atas, memicu keingintahuan Peneliti untuk melakukan penelitian lebih lanjut, terkait dengan gambaran restrukturisasi yang dilakukan dalam tataran implementasi yang dilalui, baik melalui prosesi Kepailitan maupun prosesi PKPU, termasuk juga model restrukturisasi utang maupun model restrukturisasi perusahaannya. Hal ini menjadi menarik karena selain kelanjutan dari penelitian Peneliti di tahun 2014, juga dapat diketahui lebih lanjut mengenai hal-hal yang menyebabkan rencana perdamaian disetujui oleh kreditornya dan begitu juga sebaliknya. Gambaran implementasi restrukturisasi ini akan dapat menjawab pertanyaan mengapa terdapat sebagian rencana perdamaian yang tidak dapat memuaskan kepentingan kreditor sebagaimana dimaksud di atas.

Berdasarkan paparan latar belakang di atas, maka perlu disusun rumusan masalah penelitian ini, yang juga menjadi ruang lingkup dan batasan terhadap penelitian ini. Adapun rumusan masalah penelitian tersebut adalah "Bagaimana implementasi restrukturisasi yang terjadi di dalam prosesi Kepailitan dan prosesi Penundaan Kewajiban Pembayaran Utang (PKPU) di Indonesia?”.

Tujuan penelitian ini adalah untuk mendapatkan deskripsi restrukturisasi dalam praktik tentang prosedur kepailitan dan Penundaan Kewajiban Pembayaran Utang di Indonesia.

Manfaat bagi akademisi adalah mendapatkan adalah penelitian ini dapat menambah wawasan terkait implementasi restrukturisasi dalam proses kepailitan dan Penundaan Kewajiban Pembayaran Utang di Indonesia, sedangkan manfaat bagi praktisi, debitor dan kreditor adalah penelitian ini dapat menjadi panduan untuk mengoptimalkan rencana restrukturisasi yang diatur oleh debitor.

Restrukturisasi adalah penataan kembali atau dapat diartikan sebagai peninjauan ulang akan utang ${ }^{3}$. Berdasarkan pengertian tersebut maka restrukturisasi dapat diklasifikasikan sebagai restrukturisasi perusahaan dan restrukturisasi utang. Restrukturisasi utang, sebagaimana halnya juga banyak diimplementasikan dalam praktek perbankan, menurut Sutan Remy Sjahdeini4, dapat berbentuk penjadwalan kembali terhadap pembayaran utang (rescheduling), juga memberikan masa tenggang (grace period) yang baru atau memberikan moratorium kepada debitor,

\footnotetext{
${ }^{3}$ Em Zui Fajri and Ratu Aprilia Senja, Kamus Lengkap Bahasa Indonesia (Jakarta: Difa Publisher, n.d.).

4 Sutan Remy Sjahdeini, Hukum Kepailitan: Memahami Faillissementsverordening Juncto Undang-Undang No.4 Tahun 1998 (Jakarta: Pustaka Utama Grafiti, 2002).
} 
memberikan persyaratan kembali perjanjian utang (reconditioning), pengurangan jumlah utang pokok (haircut), pengurangan atau pembebasan jumlah bunga yang tertunggak, denda dan biaya-biaya lain, penurunan tingkat suku bunga, pemberian utang baru, dan konversi utang menjadi modal perseroan (debt for equity conversion atau disebut debt equity swap), penjualan aset yang tidak produktif atau yang tidak langsung diperlukan untuk kegiatan usaha perusahaan debitor untuk melunasi utang, dan bentuk-bentuk lain yang tidak bertentangan dengan peraturan perundang-undangan yang berlaku.

Secara keilmuan, restrukturisasi perusahaan mempunyai ruang lingkup yang begitu luas mengingat strategi dalam penentuan restrukturisasi juga sangat bervariasi. Asset sales, equity carve-out, maupun spin off. ${ }^{5}$ Asset sales diartikan sebagai sebuah penjualan aset-aset dari perusahaan. Sedangkan equity carve-out adalah penawaran untuk dapat diinvestasikan kepada publik, baik sebagian ataupun seluruhnya, tentu saja dengan cara melakukan proses IPO (Initial Public Offering). Spin off adalah membagi saham secara pro rata kepada pemegang saham induknya. Equity carve-out dan spin off akan menciptakan badan hukum perusahaan yang baru, sedangkan asset sales lebih ke arah aset untuk badan hukum perusahaan lain. Restrukturisasi perusahaan dalam bentuk alternatif lain adalah dengan melakukan merger maupun akuisisi pada perusahaan yang lain, baik itu bisa berbentuk sebagai anak perusahaan, atau sebagai perusahaan mandiri yang berdiri sendiri. ${ }^{6}$ Dalam hal ini Clark dan Ofek ${ }^{7}$ menyimpulkan bahwa dalam sebagian besar kasus, akuisisi tidak sukses dalam merestrukturisasi perusahaan yang sedang dalam kondisi keuangan yang terpuruk. Meskipun demikian, mereka juga menyimpulkan tidak ada lagi suatu pilihan yang lebih baik lagi kecuali pilihan akuisisi yang tersedia pada waktu itu.

\section{METODE PENELITIAN}

Penelitian ini menggunakan jenis penelitian hukum normatif untuk mendapatkan gambaran implementasi restrukturisasi yang terjadi dalam prosesi

\footnotetext{
5 J. Fred Weston, Mark L. Mitchell, and J. Harold Mulherin, Takeovers, Restructuring, and Corporate Governance, Fourth Edi. (Upper Saddle River, New Jersey, USA: Pearson Education Inc., 2004).

${ }^{6}$ Ibid.

7 Kent Clark and Eli Ofek, "Mergers as a Mean of Restructuring Distressed Firms: An Emperical Investigation," Journal of Financial and Quantitative Analysis (1994).
} 
Kepailitan dan PKPU. Oleh karena sifatnya, data sekunder, dalam hal ini putusan pengadilan terkait, untuk menjadi bagian yang utama supaya menjawab segala permasalahan penelitian yang muncul. Penelitian ini juga menggunakan data primer yang didapatkan dari studi lapangan sebagai pendukung dalam analisis data sekunder yang sudah didapatkan sebelumnya. Data primer didapatkan dengan cara wawancara secara komprehensif (indepth interview) dengan narasumber yang dipilih oleh Peneliti untuk mendapatkan model-model restrukturisasi dalam tataran praktik. Penelitian ini dilakukan di domisili Peneliti berada, yaitu di Kota Batam. Meskipun demikian, dalam rangka mendapatkan data primer dengan narasumber yang dipilih oleh Peneliti sebelumnya, maka Peneliti mengadakan wawancara dengan beberapa narasumber dengan tempat yang berbeda.

Setelah dilakukan analisis kebutuhan data, baik data sekunder maupun data primer, terutama berkaitan langsung dengan permasalahan penelitian ini, Peneliti selanjutnya melakukan pengumpulan dengan cara sebagaimana tersebut di atas untuk masing-masing jenis data. Dalam melakukan pemilihan narasumber, Peneliti menggunakan prinsip yang dianut di dalam non probability sampling design sebagaimana pendapat dari Soerjono Soekanto, yang menyebutkan bahwa non probability sampling design tidak diikuti teori probabilita, karena unit-unit populasi tidak dipilih sebagai unit sampel yang berkedudukan sama ${ }^{8}$. Sedangkan dalam penerapannya, Peneliti menggunakan bentuk judmental sampling atau purposive sampling. Dalam hal ini berdasarkan pendapat dari Soerjono Soekanto tersebut, Peneliti menetapkan syarat-syarat tertentu yang harus dipenuhi untuk memilih unsur-unsur dari sampel, sehingga dapat menjadi anggota sampel.

Demikian data-data yang diperlukan sudah terkumpul, baik itu data primer maupun data sekunder, data tersebut kemudian dianalisis berdasarkan metode yang dipilih oleh Peneliti, yaitu menggunakan pendekatan kualitatif untuk dapat menggali aspek yuridis dalam tataran praktik dari permasalahan penelitian. Di dalam penelitian ini, data yang diperoleh kemudian diuraikan dengan pendekatan kualitatif. Penganalisisan data selanjutnya ditata secara kualitatif dengan cara berpikir deduktif.

${ }^{8}$ Soerjono Soekanto, Pengantar Penelitian Hukum (Jakarta: Penerbit Universitas Indonesia, 1986). 


\section{PEMBAHASAN DAN ANALISIS}

Rencana perdamaian di prosesi kepailitan maupun penundaan kewajiban pembayaran utang merupakan rancangan restrukturisasi. Hal ini terlihat dalam setiap rancangan atau rencana perdamaian yang disajikan oleh debitor, baik di dalam prosesi kepailitan maupun penundaan kewajiban pembayaran utang, selalu mengarah pada teori restrukturisasi utang. Dari sekian praktek restrukturisasi di atas, oleh Gunadi selanjutnya dirangkum menjadi beberapa metode dan cara restrukturisasi yang lazim digunakan di dunia usaha, yaitu :9

1) Rescheduling adalah metode perpanjangan waktu pengembalian utang atau penjadwalan kembali terhadap utang debitor. Rescheduling dilakukan dengan cara mengubah jangka waktu pelunasan yang diatur dalam perjanjian utang piutang.

2) Hair Cut adalah pemberian potongan atau pengurangan atas pembayaran bunga dan atau utang. Metode ini dilakukan untuk mencegah kerugian yang lebih besar lagi apabila debitor tidak dapat membayar utangnya.

3) Debt to asset swap merupakan pengalihan aset milik debitor dengan tujuan untuk dikuasai oleh kreditor. Aset yang dikuasai tersebut hanya bersifat sementara, sampai nanti dibeli pihak lain dan hasilnya dipakai untuk melunasi utang debitor.

4) Debt to equity swap dilakukan dengan cara mengubah utang menjadi bagian modal, hal ini dapat dilakukan apabila kreditor melihat debitor memiliki nilai dan prospek bisnis yang baik.

Dari sekian bentuk restrukturisasi utang yang diajukan oleh debitor kepada kreditornya, yang paling sering adalah penjadwalan kembali pelunasan utang (rescheduling). Hal ini disampaikan oleh Hakim Pengawas di Pengadilan Niaga pada Pengadilan Negeri Jakarta Pusat, yang menyatakan bahwa rescheduling menjadi rencana favorit para debitor dalam prosesi di kepailitan dan penundaan kewajiban pembayaran utang. Restrukturisasi tersebut bisa dilaksanakan dalam waktu yang pendek maupun panjang, bahkan ada juga debitor yang mengajukan rencana

\footnotetext{
${ }_{9}^{9}$ Gunadi, Restrukturisasi Perusahaan Dalam Berbagai Bentuk Dan Pemajakannya (Jakarta: Salemba Empat, 2001).
} 
perdamaian berupa rescheduling sampai dengan puluhan tahun. Kreditor di dalam prakteknya lebih suka menerima rencana perdamaian rescheduling dalam waktu yang pendek, antara 5-6 tahun paling lama, mengingat dalam waktu tersebut masih terjangkau bagi kreditor untuk menunggu. Apalagi bagi kreditor yang telah mengeluarkan segala modalnya untuk dapat berbisnis dengan debitor, yang pada akhirnya pembayarannya pun macet.

Salah satu perkara yang melaksanakan model rescheduling dalam rencana perdamaiannya adalah perkara No. 40/Pdt.Sus.PKPU/2015/PN.Niaga.Jkt.Pst yang diajukan kepada masing-masing kreditornya, dimana PT. Cahaya Adiputra Sentosa dan Tjung Ferry Kurniawan sebagai debitornya. Dalam perkara ini pada awalnya terdapat kreditor yang tidak setuju dengan rencana perdamaian yang disampaikan debitor, tetapi oleh karena sebagian besar kreditor konkuren, yaitu 6 kreditor konkuren atau $84 \%$ dari tagihan sementara yang diakui dan hadir, dan 4 kreditor separatis atau $84 \%$ dari tagihan sementara yang diakuhi dan hadir, maka rencana perdamaian pada akhirnya disetujui untuk dilakukan pengesahan (homologasi). Di dalam Perjanjian Perdamaian yang dihomologasi tidak disebutkan bagaimana model reschedulingnya secara detail, tetapi merujuk pada rencana perdamaian yang dilampirkan.

Dalam perkara tertentu, ada debitor yang mengajukan restrukturisasi usaha dan juga pembayaran utang sebagaimana mestinya. Seperti dalam perkara No. 21/Pdt.Sus/PKPU/2014/PN.Niaga.Jkt.Pst yang dalam hal ini Koperasi Cipaganti Karya Guna Persada sebagai debitornya. Setelah melewati sekian kali pertemuan antara Tim Pengurus PKPU, Para Kreditor dan Tim Restrukturisasi dari debitor, maka kemudian diputuskan dua jalan tersebut dilakukan oleh debitor. Jalan restrukturisasi usaha dengan cara memperbaiki kinerja debitor. Dalam hal ini kreditor menginginkan suatu kepastian dari debitor sehingga meminta debitor untuk memilih PT. Pooling Asset sebagai unit usaha otonom bersifat sementara, dimana PT. Pooling Asset membuat rancangan yang bersifat rekonstruksi untuk penyelesaian kewajiban dengan mitra usaha melalui skema pengakuan utang dengan Cipaganti Group. Utang tersebut dijamin dengan aset berupa saham perusahaan dan bentuk aktiva tetap lainnya. Andianto Setiabudi tetap menjalankan management dengan pengawasan penuh oleh Komite Investasi Mitra Usaha (KIMU) dan PT. Pooling Asset. 
KIMU adalah inkubator dari PT. Pooling Asset sebelum terbentuknya perusahaan tersebut, dengan tugas salah satunya menunjuk direksi dan komisaris PT. Pooling Asset dalam masa transisi dan bersama dengan pengurus debitor dan Manajemen Cipaganti Group membuat rencana strategis PT. Pooling Asset, menjual aset untuk kepentingan Mitra Koperasi (kreditor konkuren), melakukan optimalisasi aset yang dimiliki Cipaganti Group, dan menetapkan persetujuan rencana Corporate Action. Terhadap pembayaran utang kepada para kreditornya, debitor tetap akan melaksanakan sesuai dengan yang telah dijanjikan sebelumnya. Khusus untuk kreditor konkuren, debitor meminta restrukturisasi utang berupa penghapusan kewajiban terkait bagi hasil yang tertunggak termasuk dendanya sampai dengan tanggal 19 Mei 2014, yang dalam hal ini terkategori sebagai haircut.

Permasalahan pengajuan rencana perdamaian kepada kreditor sebenarnya merupakan cerminan keberlangsungan usaha, dengan kata lain jika debitor mengajukan rencana perdamaian yang materinya dalam batas kewajaran kreditor, maka itu menandakan bahwa debitor masih going concern, yang berarti debitor masih dapat melanjutkan usahanya dengan baik. Going concern juga dapat dilihat dari sisi analisis solvabilitasnya. Menurut Kukuh Komandoko Hadiwidjojo ${ }^{10}$, analisis solvabilitas dilakukan dengan cara membandingkan keadaan total aset dengan total kewajiban. Suatu perusahaan dikatakan memiliki kondisi yang baik apabila perusahaan dapat memenuhi kewajibannya, jangka pendek maupun jangka panjang. Dalam hal ini, analisis terhadap solvabilitas dilakukan untuk memastikan apakah aset yang dimiliki oleh debitor mampu untuk mendukung seluruh kegiatan bisnisnya.

Dalam beberapa perkara, ada juga debitor yang tidak mengajukan rencana perdamaian apapun, karena debitor menyadari bahwa debitor tidak akan mungkin going concern, dan memang berniat untuk melikuidasi segala asetnya untuk pembayaran utang-utang kepada kreditornya. Hal ini tampak pada perkara No. 08/PAILIT/2011/PN.Niaga.Medan yang dalam hal ini PT. Gimmil Industrial Bintan sebagai debitornya. Dalam perkara ini, PT. Gimmil Industrial Bintan dinyatakan pailit oleh Pengadilan Niaga pada Pengadilan Negeri Medan atas permohonan pernyataan pailit yang diajukan oleh Salmiyati dan kawan-kawan, yang merupakan karyawan

10 Kukuh Komandoko Hadiwidjojo, "Metode Dan Konsep Restrukturisasi Sebagai Pelaksanaan Asas Kelangsungan Usaha Dalam Penundaan Kewajiban Pembayaran Utang (PKPU) Terhadap Perusahaan Publik Dan Non Publik," Jurnal Hukum \& Pasar Modal Himpunan Konsultan Hukum Pasar Modal (HKHPM) Vol.VII Ed (2016): 72. 
dari PT. Gimmil Industrial Bintan. Perkara ini bermula dengan adanya pengumuman dari PT. Gimmil Industrial Bintan yang akan menutup operasional perusahaan karena tidak lagi mendapatkan pesanan dari pelanggan perusahaan. Dari pengumuman tersebut lalu menimbulkan gejolak di kalangan karyawan, dan mereka menuntut perusahaan pesangon yang berkali lipat, sedangkan PT. Gimmil Industrial Bintan hanya mampu membayar pesangon sejumlah satu kali paket pesangon bagi masing-masing karyawan. Pada akhirnya Pengadilan Niaga pada Pengadilan Negeri Medan menyatakan PT. Gimmil Industrial Bintan pailit dengan segala akibat hukumnya, dan PT. Gimmil Industrial Bintan pun tidak mau mengajukan rencana perdamaian apapun di dalam rapat kreditor, dan akibatnya harta debitor dinyatakan dalam kondisi insolvensi. Meskipun demikian, pada saat bersamaan dengan pemberesan boedel pailit, PT. Gimmil Industrial Bintan yang telah dinyatakan insolvensi oleh Hakim Pengawas, tetap mengajukan upaya hukum kasasi. Di tingkat kasasi, PT. Gimmil Industrial Bintan memenangkan perkara. Tetapi likuidasi sebagian aset sudah terlanjut dilakukan dan dibagikan kepada sebagian kreditor, mengingat sejak putusan pailit, kurator berwenang untuk melakukan pemberesan dan likuidasi boedel pailit, sampai dengan ada pencabutan status pailit oleh hakim kasasi, atau jika ada perdamaian yang telah dihomologasi oleh Pengadilan Niaga. Kreditor yang telah menerima pembayaran dari hasil pemberesan boedel pailit tersebut adalah karyawan sebagai kreditor preferen sebesar Rp 7.302.901.792,- . Sedangkan KPP Pratama Batam sebagai kreditor preferen dengan nilai tagihan sebesar Rp 772.610.404,- dan KPP Madya Batam sebagai kreditor preferen dengan nilai tagihan sebesar Rp 11.973.885.980,- belum diselesaikan pembayarannya oleh kurator. Lepas dari permasalahan apapun di dalam prosesnya, sampai dengan saat ini perusahaan ini sudah tidak lagi beroperasi di Indonesia.

Menurut Ricardo Simanjuntak ${ }^{11}$, permasalahan di atas bisa terjadi karena debitor tidak mengajukan usulan perdamaian berdasarkan ketentuan Pasal 145 Undang-Undang No. 37 Tahun 2004, yang tentu akan menimbulkan konsekuensi bagi debitor yaitu dinyatakan insolvensi. Status insolvensi akan menjadi dasar dari kurator untuk memulai melakukan penjualan atau likuidasi harta debitor. Keadaan

11 Ricardo Simanjuntak, “Aspek Hukum Kepailitan Perusahaan Publik Di Pasar Modal," Jurnal Hukum \& Pasar Modal Vol. V Ed (2013): 57-58. 
tersebut berpotensi menimbulkan ketidakadilan dan ketidakpastian hukum bagi debitor karena masih terbuka kemungkinan bagi debitor untuk membatalkan putusan pailit melalui upaya hukum kasasi. Sangat memungkinkan bagi seluruh harta debitor telah terjual ketika debitor pada akhirnya berhasil membatalkan putusan pailit yang dijatuhkan oleh pengadilan. Dalam keadaan tersebut maka tidak mungkin bagi kurator untuk mengembalikan harta-harta yang telah dijualnya tersebut, sehingga menimbulkan kerugian bagi debitor. Keharusan untuk mengajukan usulan perdamaian menjadi titik penting supaya menghindarkan posisi insolvensi ini, meskipun debitor masih mengupayakan kasasi maupun peninjauan kembali.

Hal yang paling utama dalam pengajuan rencana perdamaian di dalam prosesi kepailitan dan penundaan kewajiban pembayaran utang adalah pengetahuan debitor maupun kuasa hukumnya terkait tentang kepailitan dan penundaan kewajiban pembayaran utang. Terkadang di dalam proses rapat kreditor, kuasa hukum debitor membantah segala dalil dari kreditor tanpa dapat membuktikan dalil bantahannya tersebut, seolah-olah masih dalam posisi persidangan. Padahal dalam waktu rapat kreditor berlangsung, adalah sebuah pertemuan antara debitor dengan kreditornya, guna pembahasan mengenai verifikasi piutang dan rencana perdamaiannya. Dalam kondisi tersebut, bahkan debitor melalui kuasa hukumnya tidak mau mengajukan rencana perdamaian apapun. Pada akhirnya, debitor lah yang dirugikan, karena ia menjadi dalam posisi insolvensi, jika di dalam prosesi kepailitan, dan dilanjutkan prosesnya dalam pemberesan boedel pailit meskipun debitor masih mengajukan upaya kasasi, dalam posisi pailit serta langsung insolvensi, jika dalam prosesi penundaan kewajiban pembayaran utang, dan dilanjutkan prosesnya dalam pemberesan boedel pailit.

Terkait pemahaman yang kurang dari debitor maupun kuasa hukumnya, terkadang juga terjadi ketika debitor maupun kuasa hukumnya tidak mengetahui bagaimana membuat rencana perdamaian yang baik, yang secara futuristik bisa mengakomodasi kepentingan para kreditornya tetapi sesuai dengan kemampuan debitor. Karena kekurangpahaman tersebut, maka rencana perdamaian yang disampaikan oleh debitor hanya melihat dari kepentingan sepihak debitor saja, padahal konsekuensi terhadap ditolaknya rencana perdamaian yang diajukan adalah insolvensi bagi prosesi kepailitan, dan pailit dilanjutkan dengan insolvensi bagi 
prosesi penundaan kewajiban pembayaran utang. Ketidakpahaman ini, terutama bagi kuasa hukum debitor, seringkali karena penguasaan materi untuk menyusun sebuah rencana perdamaian terutama dari sisi penghitungan ekonominya.

Dalam implementasinya juga, rencana perdamaian baik di dalam prosesi kepailitan maupun penundaan kewajiban pembayaran utang, jarang sekali menggunakan tim ahli, sehingga dalam pengajuan rencana perdamaian berpotensi untuk diterima oleh para kreditornya. Pengalaman praktisi kepailitan dan penundaan kewajiban pembayaran utang menunjukan bahwa debitor yang tidak dapat menyusun rencana perdamaian dengan baik akan mengarahkan debitor dalam kesulitan, baik harta debitor akan masuk ke ranah insolvensi dan hartanya dilikuidasi dalam prosesi kepailitan atau debitor dinyatakan pailit dan insolvensi serta hartanya dilikuidasi dalam prosesi penundaan kewajiban pembayaran utang. Sutan Remy Sjahdeini ${ }^{12}$ mengatakan bahwa karena penyusunan rencana perdamaian itu tidak mudah, maka diperlukan suatu tim konsultan ahli yang dibentuk oleh debitor sebagai pihak yang harus mengajukan rencana perdamaian, yang terdiri dari akuntan publik, konsultan hukum, konsultan manajemen keuangan dan bisnis, dan perusahaan penilai. Selanjutnya masing-masing anggota konsultan ahli akan bertugas sesuai dengan kemampuannya masing-masing. Akuntan publik akan menangani aspek keuangan dari perusahaan debitor dan para penjamin utang debitor. Konsultan hukum akan menangani aspek hukum dari perusahaan debitor dan para penjamin utang debitor. Konsultan manajemen keuangan dan bisnis akan menangani aspek manajemen dan aspek bisnis dari perusahaan debitor. Perusahaan penilai akan melakukan penilaian terhadap aset perusahaan debitor dan aset dari para penjamin utang debitor.

Menurut Bapak Deni Purba di dalam praktiknya tim ahli seperti itu bisa saja disediakan oleh debitor dengan ataupun atas rekomendasi kurator jika dalam prosesi kepailitan dan pengurus jika dalam prosesi penundaan kewajiban pembayaran utang. Kurator maupun pengurus mempunyai potensi untuk membantu debitor dalam menyusun rencana perdamaian tersebut, karena kurator dan pengurus biasanya mempunyai tim ahlinya sendiri, terutama akuntan publik dan penilai independen. Secara yuridis, kedudukan kurator dan pengurus adalah mandiri dan independen, 
dan oleh karenanya keberadaannya ditunjuk oleh pengadilan, meskipun secara sosiologis berpotensi berpihak kepada salah satu pihak karena keberadaannya dibawa oleh kreditor atau debitor di dalam permohonan, baik permohonan pernyataan pailit maupun permohonan penundaan kewajiban pembayaran utang. Posisi sosiologis ini yang membawa dampak bagi sikap penolakan debitor terhadap keberadaan kurator maupun pengurus. Debitor dalam hal ini berperan atas potensi kegagalannya sendiri. Kurator maupun pengurus yang secara yuridis adalah independen, sebenarnya dapat membantu debitor jika debitor membuka diri dalam menggambarkan kondisi perusahaan. Perkara No. 08/PAILIT/2011/PN.Niaga.Medan adalah contoh nyata bahwa debitor menolak keberadaan kurator meskipun tidak secara frontal dilakukannya. PT. Gimmil Industrial Bintan sebagai debitor dalam perkara tersebut sebenarnya menolak mekanisme kepailitan untuk menyelesaikan permasalahan dengan karyawannya, tetapi Pengadilan Niaga pada Pengadilan Negeri Medan memutuskan berbeda, meskipun pada akhirnya Mahkamah Agung memutuskan bahwa permasalahan tersebut harusnya diselesaikan di dalam mekanisme penyelesaian perselisihan hubungan industrial.

Hal di atas dapat dipahami, mengingat terkadang terdapat kurator maupun pengurus yang mendukung proses mengkebiri aset debitor daripada menjalankan jiwa dari Undang-Undang No. 37 Tahun 2004, terutama dalam memberikan perlindungan hukum bagi kepentingan semua pihak, debitor dan kreditor. Putusan pailit yang sifatnya serta merta ini dapat digunakan oleh pihak yang tidak bertanggungjawab tertentu untuk tidak terjadinya perdamaian sehingga boedel pailit tetap dapat dilikuidasi. Demikian juga terjadi di dalam proses penundaan kewajiban pembayaran utang, dimana pihak-pihak tertentu dapat mengarahkan pada proses gagalnya perdamaian, sehingga debitor dinyatakan pailit dan dalam keadaan insolvensi, serta harta debitor pun dilikuidasi. Bagi praktisi kepailitan, seperti Deni Purba, SH, MH, yang paling penting adalah pemahaman yang sama mengenai jiwa dari Undang-Undang Kepailitan dan Penundaan Kewajiban Pembayaran Utang itu sendiri, dan bukan hukum materiil dan formilnya belaka. Sehingga kepentingan pihak-pihak yang ada di dalam prosesi kepailitan maupun prosesi penundaan kewajiban pembayaran utang tetap dapat dilindungi, berdasarkan hukum. 
Berkaitan dengan kelayakan utang debitor untuk dimungkinkan direstrukturisasi, maka setidaknya dapat menggunakan pandangan dari Sutan Remy Sjahdeini ${ }^{13}$, utang debitor layak untuk direstrukturisasi apabila :

a. Masih adanya prospek usaha yang concern dari debitor sehingga dapat melunasi utang tersebut apabila perusahaan debitor diberi penundaan pembayaran utang tersebut dalam jangka waktu tertentu, baik dengan atau tanpa diberi keringanan kondisi dan/atau diberikan utang baru. Salah satu bentuknya adalah Prakarsa Jakarta atau the Jakarta Inisiative di mana menentukan jangka waktu tidak lebih dari delapan tahun.

b. Utang debitor dinilai patut untuk dilakukannya restrukturisasi apabila para kreditor akan memperoleh pelunasan utang mereka yang jumlahnya lebih besar melalui restrukturisasi daripada apabila perusahaan debitor dinyatakan pailit.

c. Jika persetujuan restrukturisasi menjadi lebih menguntungkan bagi para kreditor daripada apabila tidak dilakukan restrukturisasi.

Dalam tataran implementasi restrukturisasi utangnya, ternyata menurut hasil wawancara dengan Bapak Deni Purba, SH, MH, kurator kepailitan dan pengurus PKPU, debitor banyak melakukan modifikasi terhadap rescheduling, seperti menjual aset dari debitor sebagian, mencari equitas baru, atau dengan model lain yang selain rescheduling juga mengkonversi utang menjadi saham (debt to equity swap), sehingga kreditor yang bersedia dapat menjadi pemegang saham dari perusahaan debitor. Hal ini setidaknya pernah dilakukan dalam perkara No. 03/PKPU/2006/PN.Niaga,Jkt.Pst jo. No. 05/Pailit/2006/PN.Niaga.Jkt.Pst. Di dalam perkara tersebut PT. Argo Pantes, Tbk awalnya dimohonkan pailit oleh Indo Plus BV., terkait dengan utang yang telah jatuh tempo sebesar US\$12,000,000 (dua belas juta dollar Amerika Serikat), tetapi selanjutnya PT. Argo Pantes, Tbk melakukan counter dengan cara memohon Penundaan Kewajiban Pembayaran Utang. Di dalam PKPU-nya PT. Argo Pantes, Tbk kemudian mengajukan rencana perdamaian dengan para kreditornya, dengan mengajukan debt to equity swap, dan disetujui oleh para kreditornya. 
Penawaran debt to equity swap juga pernah dilakukan oleh PT. Sekar Laut, Tbk kepada para kreditornya melalui mekanisme penundaan kewajiban pembayaran utang di Pengadilan Niaga pada Pengadilan Negeri Surabaya dengan perkara No. 08/PKPU/2005/PN.Niaga.Sby, yang selanjutnya disetujui oleh para kreditornya. Pola restrukturisasinya adalah berupa restrukturisasi 10\% dari utang pokok terhadap utang kreditor bank sindikasi senilai US \$27,874,500, selanjutnya dijadikan utang jangka panjang selama 10 tahun dan bunga 2\% dengan masa tenggang dua tahun. Sisanya sebanyak US\$ 25,087 yang merupakan sisa dari utang pokok dikonversi ke dalam saham perseroan dengan nilai Rp 500. Dengan demikian, 519.302.000 lembar saham atau setara dengan 76,2\% akan diterima oleh kreditor sindikasi. Selain itu, saham perseroan PT. Sekar Laut, Tbk sebanyak 86.625.500 lembar saham atau $12,7 \%$ dari total saham perseroan menjadi hasil konversi dari utang PT. Sekar Laut, Tbk kepada Bank BNI sebesar Rp 54,308 milyar.

Debt to equity swap secara teori dapat dikategorikan sebagai bagian dari pengambilalihan suatu perusahaan, dalam hal terjadi peralihan pengendalian atas perusahaan yang bersangkutan, mengingat Pasal 125 ayat (1) Undang-Undang No. 40 Tahun 2008 menyatakan pada prinsipnya bahwa pengambilalihan dapat dilakukan atas saham yang akan dikeluarkan. Dalam debt to equity swap, setidaknya baik pemegang saham maupun perseroan terbatas akan mengeluarkan sejumlah saham di dalam saham portopel guna menggantikan kedudukan utang, dengan harapan nilai utang menjadi tidak ada lagi, atau setidaknya menjadi berkurang. ${ }^{14}$ Dalam konsep ini, yang patut diwaspadai adalah mengenai aspek corporate control, dimana pemegang saham yang baru masuk dapat berpotensi menjadi pengendali perusahaan, dan mengarahkan perusahaan untuk kepentingannya, dan memberikan warna budaya perusahaan yang baru, atau lebih parahnya berpotensi merugikan kepentingan pemegang saham awal. Jika memang demikian, yang patut dihindarkan adalah motif kreditor yang sengaja memberikan bantuan sehingga menjadi utang yang sulit untuk dikembalikan oleh debitor, dengan maksud nantinya akan dilakukan debt to equity swap dan kreditor tersebut akan mengendalikan perusahaan debitor.

\footnotetext{
14 David Kairupan, "Kepemilikan Dan Pengendalian Perusahaan Terbuka Oleh Pihak Asing: Suatu Analisa Yuridis Dan Komparatif," Jurnal Hukum \& Pasar Modal Himpunan Konsultan Hukum Pasar Modal (HKHPM) Vol. V Ed. (2014): 41.
} 
Dalam praktiknya, debitor yang mengajukan rencana perdamaian berupa rescheduling dalam jangka waktu yang pendek biasanya melakukan secara mandiri operasional perusahaannya tanpa bantuan pihak lain terutama kreditor. Tetapi jika rescheduling lebih dari 5 tahun, maka biasanya debitor dibantu oleh kreditornya, terutama kreditor dari bidang keuangan, yaitu perbankan. Dalam implementasinya, kreditor perbankan bersedia membantu debitor jika ia mempunyai itikad baik dan masih berpotensi going concern, dengan cara mengucurkan penambahan kredit ke debitor. Dari dana kredit ini nantinya debitor akan mengelolanya untuk menjalankan kegiatan usahanya, dengan pengawasan ketat dari kreditor.

Di dalam implementasinya, berdasarkan wawancara, bisa dikatakan tidak pernah kreditor di dalam rapat kreditor di prosesi kepailitan mengusulkan untuk debitor tetap melanjutkan usahanya, sehingga nantinya dapat membayar utangutangnya kepada para kreditor, diluar rencana perdamaian. Artinya debitor meskipun berstatus dalam pailit, tetapi masih diperkenankan untuk melanjutkan kegiatan usahanya, dengan diawasi oleh pengadilan melalui kurator. Hal ini dibuka kesempatan dalam Pasal 104 ayat (1) Undang-Undang No. 37 Tahun 2004 yang menyatakan:

"Berdasarkan persetujuan panitia kreditor sementara, kurator dapat melanjutkan usaha debitor yang dinyatakan pailit walaupun terhadap putusan pernyataan pailit tersebut diajukan kasasi atau peninjauan kembali."

Hal yang sama juga dibuka kesempatan dalam Pasal 179 ayat (1) UndangUndang No. 37 Tahun 2004 sebagai berikut :

"Jika dalam rapat pencocokan piutang tidak ditawarkan rencana perdamaian atau jika rencana perdamaian yang ditawarkan tidak diterima, kurator atau kreditor yang hadir dalam rapat dapat mengusulkan supaya perusahaan debitor pailit dilanjutkan."

Dalam hal ini hukum telah memberikan jalan, tetapi faktanya kreditor tidak banyak yang menginginkan jalan ini terjadi. Hal yang paling mudah dipikirkan kreditor adalah mendapatkan pembayaran secepatnya. Hal senada disampaikan oleh Hakim Pengawas di Pengadilan Niaga pada Pengadilan Negeri Jakarta Pusat, yang 
menyampaikan bahwa pemicu kegagalan perdamaian, selain ketidakpahaman para pihak, debitor dan kreditor maupun kuasa hukumnya, juga disebabkan karena kreditor yang menginginkan pembayaran secara segera, tanpa memperhatikan lagi kepentingan debitor.

Tidak kalah pentingnya lagi adalah kelanjutan dari proses perdamaian, baik yang dijalankan melalui prosesi kepailitan maupun prosesi penundaan kewajiban pembayaran utang. Terkadang perjalanan restrukturisasi yang telah disepakati tersebut tidak lancar sebagaimana dibayangkan sebelumnya, yang berakibat pada pailitnya debitor, halmana berdasarkan pada Pasal 170 ayat (1) jo. Pasal 175 ayat (1) dan (2) Undang-Undang No. 37 Tahun 2004, jika dalam prosesi kepailitan dan Pasal 291 ayat (1) dan (2) Undang-Undang No. 37 Tahun 2004, jika dalam prosesi penundaan kewajiban pembayaran utang. Pasal 170 ayat (1) Undang-Undang No. 37 Tahun 2004 menyatakan pada prinsipnya bahwa "kreditor dapat menuntut pembatalan suatu perdamaian yang disahkan jika debitor lalai memenuhi isi perdamaian tersebut". Akibatnya diatur di dalam Pasal 175 ayat (1) dan (2) UndangUndang No. 37 Tahun 2004 yang pada prinsipnya menyatakan bahwa "setelah kepailitan dibuka kembali maka tidak dapat lagi ditawarkan perdamaian, dan kurator wajib seketika memulai dengan pemberesan harta pailit". Sedangkan pasal 291 ayat (1) dan 292 Undang-Undang No. 37 Tahun 2004 merujuk pada ketentuan Pasal 170 dan 171 Undang-Undang No. 37 Tahun 2004, dan di dalam ayat (2)-nya dinyatakan pada prinsipnya bahwa "apabila terdapat putusan pembatalan perdamaian dalam penundaan kewajiban pembayaran utang, maka debitor juga harus dinyatakan pailit”. Selanjutnya Pasal 292 Undang-Undang No. 37 Tahun 2004 mengatur bahwa "putusan pailit yang timbul oleh karena pembatalan perdamaian tersebut di dalam Pasal 291 tidak dapat ditawarkan perdamaian", dan lebih dijelaskan lagi oleh penjelasan Pasal 292 pada prinsipnya bahwa "putusan pernyataan pailit yang mengakibatkan harta pailit debitor langsung berada dalam keadaan insolvensi". Oleh karenanya, dalam posisi perdamaian yang terbentuk oleh proses penundaan kewajiban pembayaran utang yang telah disahkan kemudian dibatalkan oleh pengadilan, akibatnya adalah pemberesan boedel pailit, tanpa melalui mekanisme pembuktian pailit lagi. 
Contoh perkara yang terjadi terkait dengan pembatalan perdamaian tersebut adalah perkara No. 03/Pdt.Sus/PKPU/2013/PN.Niaga.Jkt.Pst, dimana PT. Menara Karsa Mandiri sebagai debitornya. Di dalam rencana perdamaiannya tertanggal 7 Mei 2013 yang telah beberapa kali direvisi hingga terakhir kali pada tanggal 10 Mei 2013 telah dilakukan pemungutan suara untuk menentukan persetujuan rencana perdamaian tersebut. Setelah dilakukan homologasi terhadap rencana perdamaian tersebut berdasarkan No. 03/PKPU/2013/PN.Niaga.Jkt.Pst tanggal 24 Mei 2013. Rencana perdamaian yang disetujui dengan Er Ummi Kalsum adalah melakukan serah terima kunci beserta bangunan untuk pembelian unit apartemen pada bulan Agustus 2013 dan melakukan pemecahan sertfikat serta penandatanganan AJB paling lambat bulan Februari 2014. Rencana perdamaian yang disetujui dengan Tresna Tino Cahyadi adalah melakukan pemecahan sertifikat induk, penandatanganan AJB paling lambat Februari 2014, melakukan serah terima unit paling lambat bulan Agustus 2013, pembayaran uang sewa sebesar Rp 15.000.000,dan pembayaran uang penalti sebesar 3\% dari harga jual yaitu Rp 4.320.000,- paling lambat tanggal 8 Juni 2013. Karena PT. Menara Karsa Mandiri tidak melaksanakan isi dari rencana perdamaian tersebut, maka perusahaan ini kemudian harus merasakan kondisi pailit dan hartanya berada dalam posisi insolvensi berdasarkan Putusan pembatalan perdamaian No. 01/Pdt.Sus-Pemb.Perdamaian/2015/PN.Niaga.Jkt.Pst jo. No. 03/Pdt.Sus-PKPU/2013/PN.Niaga.Jkt.Pst.

Pembatalan perdamaian di atas merupakan cerminan kegagalan suatu restrukturisasi utang yang dijalankan oleh debitor. Berdasarkan penelitian dari Badan Pembinaan Hukum Nasional, upaya restrukturisasi dapat saja berakhir dengan kegagalan, terutama apabila : (1) adanya pelanggaran kewajiban yang ditentukan dalam Perjanjian Restrukturisasi; (2) Perseroan tidak melakukan sesuai dengan jadwal yang ditentukan dalam Perjanjian Restrukturisasi, sedangkan Komite Kreditor menolak alasan direksi perseroan terkait tidak dilakukannya sesuai jadwal tersebut; (3) Tidak disampaikannya laporan implementasi restrukturisasi yang berakibat pada ketidakpercayaan kreditor; (4) Dalam masa restrukturisasi, terjadi penurunan nilai aktiva debitor sampai melebihi $25 \%$ dari nilai semula dan penurunan tersebut menurut Komite Kreditor merugikan kepentingan kreditor; (5) Dalam masa restrukturisasi, terjadi kerugian bagi debitor sampai mengurangi modal 
perseroan hingga 50\% dan pengurangan tersebut menurut Komite Kreditor merugikan para kreditor; (6) Dalam masa restrukturisasi Direksi perseroan bertindak dengan itikad buruk dalam menjalankan kegiatan usaha perseroan debitor atau dalam melakukan pengelolaan aktivanya; (7) Adanya kesengajaan direksi perseroan untuk merugikan satu pihak atau lebih kreditornya. ${ }^{15}$

\section{PENUTUP}

\subsection{Kesimpulan}

Peneliti menyimpulkan bahwa restrukturisasi yang terjadi di dalam prosesi kepailitan dan penundaan kewajiban pembayaran utang adalah restrukturisasi utang, meskipun terdapat perkara tertentu juga termasuk restrukturisasi usaha, diawali dengan adanya rencana perdamaian, baik di dalam prosesi kepailitan maupun prosesi penundaan kewajiban pembayaran utang. Implementasi restrukturisasi melalui rencana perdamaian ini paling banyak menggunakan model rescheduling. Meskipun di dalam praktiknya ada juga yang menggunakan cara kombinasi, baik rescheduling ditambahkan dengan model penjualan aset dari debitor sebagian, mencari ekuitas baru, atau dengan model lain yang selain rescheduling juga mengkonversi utang menjadi saham (debt to equity swap). Dalam praktiknya, restrukturisasi terjadi terkendala oleh karena penyusunan rencana perdamaian yang tidak mengakomodasi kepentingan debitor dan kreditor, dan bahkan juga karena ketidakpahamannya, debitor sama sekali tidak mengajukan rencana perdamaian kepada para kreditornya. Ketidakpahaman tersebut seharusnya bisa saja dicarikan solusi dengan adanya tim konsultan ahli yang dapat mendukung kinerja debitor dalam menyusun rencana perdamaian, yangmana Undang-Undang No. 37 Tahun 2004 sebenarnya telah membuka kesempatan itu, tetapi berdasarkan wawancara pengalaman praktek para praktisi kepailitan dan penundaan kewajiban pembayaran utang, tidak pernah ada yang menggunakan jasa tim konsultan ahli. Pasca terjadinya perdamaian, baik melalui prosesi kepailitan maupun prosesi penundaan kewajiban pembayaran utang, merupakan pelaksanaan dari restrukturisasi utang tersebut.

15 Badan Pembinaan Hukum Nasional, Analisis Dan Evaluasi Hukum Tentang Restrukturisasi Utang Pada Penundaan Kewajiban Pembayaran Utang (Jakarta: Badan Pembinaan Hukum Nasional, Departemen Kehakiman dan Hak Asasi Manusia, 2000). 
Di dalam praktiknya, terdapat beberapa perkara yang menunjukkan adanya ketidakmampuan debitor dalam melaksanakan restrukturisasi dengan baik, dengan cara tidak melakukan kewajibannya sebagaimana telah disepakati dalam Perjanjian Perdamaian sebelumnya. Pada akhirnya debitor harus menanggung resiko dengan adanya pembatalan perdamaian yang berakibat pada sebuah pailit dan posisi harta debitor menjadi insolvensi. Oleh karenanya, harta debitor selanjutnya haruslah dilikuidasi oleh kurator untuk dapat dibagikan kepada para kreditor.

\subsection{Saran}

Saran ditujukan kepada pembuat hukum, untuk melakukan perubahan hukum dengan didasarkan pada hasil penelitian ini, di mana penelitian ini menjadi konsep awal untuk sebuah pembaharuan hukum, khususnya mengatur mengenai restrukturisasi utang menurut Kepailitan dan PKPU di Indonesia. Saran ditujukan kepada praktisi kepailitan, debitor dan kreditor, penelitian ini dapat digunakan untuk menjadi bahan awal dalam menyusun restrukturisasi utang di dalam prosesi Kepailitan dan PKPU sehingga mempermudah setiap pihak yang mencari jalur perlindungan hukum melalui Undang-Undang No. 37 Tahun 2004.

\section{DAFTAR PUSTAKA}

Clark, Kent, and Eli Ofek. "Mergers as a Mean of Restructuring Distressed Firms: An Emperical Investigation." Journal of Financial and Quantitative Analysis (1994).

Fajri, Em Zui, and Ratu Aprilia Senja. Kamus Lengkap Bahasa Indonesia. Jakarta: Difa Publisher, n.d.

Gunadi. Restrukturisasi Perusahaan Dalam Berbagai Bentuk Dan Pemajakannya. Jakarta: Salemba Empat, 2001.

Kairupan, David. "Kepemilikan Dan Pengendalian Perusahaan Terbuka Oleh Pihak Asing: Suatu Analisa Yuridis Dan Komparatif." Jurnal Hukum \& Pasar Modal Himpunan Konsultan Hukum Pasar Modal (HKHPM) Vol. V Ed. (2014): 41.

Kornelis, Yudi, and Florianus Yudhi Priyo Amboro. Reorganisasi Dalam United States Bankruptcy Code Terhadap Ketentuan Penundaan Kewajiban Pembayaran Utang ( PKPU) Dalam Hukum Kepailitan Indonesia Dengan Perspektif Budaya Hukum Indonesia. Batam, 2014. 
Kukuh Komandoko Hadiwidjojo. "Metode Dan Konsep Restrukturisasi Sebagai Pelaksanaan Asas Kelangsungan Usaha Dalam Penundaan Kewajiban Pembayaran Utang (PKPU) Terhadap Perusahaan Publik Dan Non Publik." Jurnal Hukum \& Pasar Modal Himpunan Konsultan Hukum Pasar Modal (HKHPM) Vol.VII Ed (2016): 72.

M.P., Manahan Sitompul. "Penyelesaian Sengketa Utang Piutang Perusahaan Dengan Perdamaian Di Dalam Atau Di Luar Proses Kepailitan (Studi Mengenai Lembaga Penundaan Kewajiban Pembayaran Utang).” Universitas Sumatera Utara, 2009.

Nasional, Badan Pembinaan Hukum. Analisis Dan Evaluasi Hukum Tentang Restrukturisasi Utang Pada Penundaan Kewajiban Pembayaran Utang. Jakarta: Badan Pembinaan Hukum Nasional, Departemen Kehakiman dan Hak Asasi Manusia, 2000.

Simanjuntak, Ricardo. “Aspek Hukum Kepailitan Perusahaan Publik Di Pasar Modal.” Jurnal Hukum \& Pasar Modal Vol. V Ed (2013): 57-58.

Sjahdeini, Sutan Remy. Hukum Kepailitan: Memahami Faillissementsverordening Juncto Undang-Undang No.4 Tahun 1998. Jakarta: Pustaka Utama Grafiti, 2002.

-_- Sejarah , Asas, Dan Teori Hukum Kepailitan. Jakarta: Kencana, 2016.

Soekanto, Soerjono. Pengantar Penelitian Hukum. Jakarta: Penerbit Universitas Indonesia, 1986.

Weston, J. Fred, Mark L. Mitchell, and J. Harold Mulherin. Takeovers, Restructuring, and Corporate Governance. Fourth Edi. Upper Saddle River, New Jersey, USA: Pearson Education Inc., 2004.

Undang-Undang No. 37 Tahun 2004 tentang Kepailitan dan Penundaan Kewajiban Pembayaran Utang. 